\section{Setting sights on US and Japan}

EUROPEAN microelectronic engineers and physicists are making a new assault on the international silicon manufacturing and design industry, now dominated by the United States and other Pacific Basin economies. That seems to be the common thread linking three projects recently unveiled.

One of these developments is the responsibility of a new venture, now but a year old, called European Silicon Structures (ES2), which says that it is now ready to make its first delivery of microchips to customers. The designs, manufactured at Exel in San Jose, California, are the first of a family eventually to be made at ES2's own complex at Aix-en-Provence in the south of France.

The group, established with an initial capital of $\$ 55$ million, is headed by $M$. Jean-Luc Grand-Clement together with some of Europe's leading names in microelectronics design, including the exchairman of Britain's largest computer company, ICL. ES2 now boasts of 130 semiconductor and business experts forming the core of the group.

The objective is to encourage the more extensive use of silicon to solve microelectronic problems, or "to give designs in silicon a wider audience". The group plans to offer designers the forms of microchip circuits best suited to their needs, even when only relatively small numbers are required and when the interval between conception and manufacture must be short.

The group intends to develop a series of joint ventures across Europe, extending the pattern of collaboration begun by the two European projects ESPRIT (the European Commission's collaborative programme in information technology) and EUREKA (the series of collaborations in technology initiated by President Mitterrand of France).

Much of ES2's software, which is crucial to the success of the venture, is to be developed by British computer scientists, probably at the group's British base at Bracknell in Berkshire. The group is hoping that its turnover by the end of the decade will be over $\$ 100$ million a year.

Meanwhile, another European microchip venture, based in Britain, but with a US arm in Colorado, has launched a new microelectronic signal processor. This is the second major development from Inmos, now a subsidiary of the consumer electronics company Thorn-EMI. Since its launch in the late 1970 s with British government funds, Inmos has been peppered with trouble. Largely the inspiration of the last Labour government, it was an attempt to give Britain a more significant presence in microchip manufac-

turing; it benefited from loans and grants before its sale to Thorn-EMI for $£ 95 \mathrm{mil}$ lion two years ago.

The mainstay of the Inmos microchip innovation is the transputer - a microchip that marries microprocessor and memory on one device. Launched almost a year ago, the transputer claimed 5 per cent of the 32-bit (input channels) microchip market in its first three months, giving Inmos an annual growth rate of $20-25$ per cent, in the face of direct competition from the US semiconductor manufacturers Intel and Motorola.

Inmos's new signal-processing microchip has been designed to attract military and civilian users. For example, phase-shift analysis of signals allows accurate determination of the position of an object without the need to engage in conventional radar scanning. 'This microchip design is expected to be particularly relevant to sonar and in modems, where coding and decoding of information is required.

But the transputer will still be the company's mainstay. The next version of the chip, called the T800 and due to be launched next year, has been designed to improve floating point arithmetic, graphics applications and the speed of calculations,

\section{Refusniks}

THE long campaign of Dr David Goldfarb, the Jewish biochemist from Moscow, to leave the Soviet Union, is over. He arrived in New York two weeks ago, for urgent medical treatment after a more than usually bizarre campaign. During the past two and a half years, he reports, he has been granted an emigration visa and had it rescinded, turned down a proposal from the KGB to compromise the journalist Nicholas Daniloff (who kept him supplied with genetically engineered insulin unobtainable in the Soviet Union) and has been accused of trying to smuggle security-related material out of the Soviet Union (the material consisted of bacteriological strains of Western origin).

According to Dr Alexander Goldfarb of Columbia University in New York, the decision to allow his father to emigrate owed much to constant pressure from the scientific community. A few weeks ago, he said, six Nobel laureates (Andre Lwoff, François Jacob, Aaron Klug, Max Perutz, Francis Crick and Renato Dulbecco) sent a telegram jointly to Mr Eduard Shevarnadze and $\mathrm{Mr}$ George Shultz appealing for David Goldfarb to be allo-

\title{
Pressure easing in Soviet Union
}

providing a basic tool for intelligent workstations. Inmos has 150 or so people working on the development of the transputer at its Bristol base, together with a further 350 staff in Colorado. Its microchips are manufactured at Newport in Wales which employs a further 650 people.

A partnership between the researchers at the British Ministry of Defence and the electronics groups Ferranti and Marconi is another sign of the new assault on the

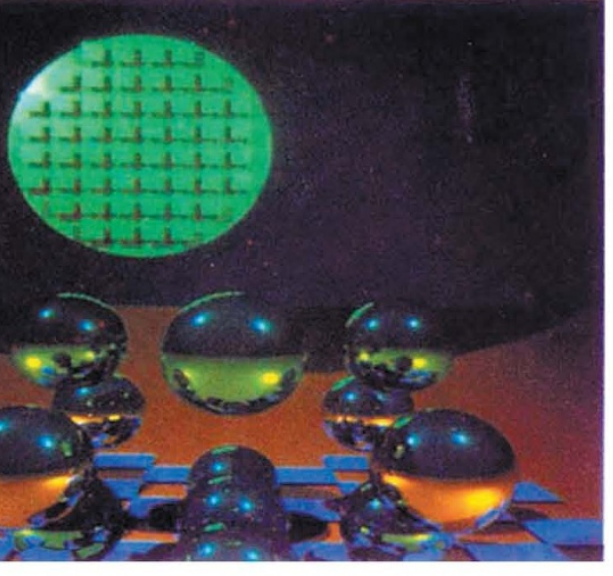
er graphics generated by the Inmos transputer. international microchip market. What is claimed to be the world's first demonstrably fault-free microprocessor, capable of reliable performance in any environment, was unveiled earlier this month by researchers from the Royal Signals and Radar Establishment, the Ministry of Defence's complex at Malvern.

Bill Johnstone

wed to leave the Soviet Union.

The Soviet authorities seem prepared at present to make concessions on the issue of Jewish refusniks. In September a refusnik mathematician, Dr Mark Freidlin, was allowed to read a paper at an international symposium on statistics in Tashkent.

This relaxation, however, has posed ethical problems in Western scientists visiting the Soviet Union, some of whom have been urged by Soviet colleagues not to press the case of the refusniks too far. Liberal-minded Soviet scientists, it is suggested, put themselves at some risk by supporting the admission of Freidlin to the Tashkent symposium, and it would be unfair of Westerners to embarrass them by insisting on visiting other refusniks in Moscow or Leningrad.

Freidlin himself, however, is anxious that his own brief return to establishment academic life in Tashkent should not be made the occasion for depriving his fellow refusnik scientists of the vists from Western colleagues on which they depend to help preserve some kind of intellectual activity while waiting for an exit visa.

Vera Rich 